\title{
PROSPECTS OF CULTIVATED MUSHROOMS USE IN TECHNOLOGY OF SAUSAGES
}

\section{T. STEPANOVA ${ }^{1 *}$, N. KONDRATJUK ${ }^{2}$, N. HAIJUAN ${ }^{1}$, K. SUPRUNENKO ${ }^{2}$}

\author{
${ }^{1}$ Department of Food Technology, Sumy National Agrarian University, Sumy, UKRAINE \\ ${ }^{2}$ Department of Food Technologies, Oles Honchar Dnipro national University, Dnipro, UKRAINE \\ 'e-mail: tetiana.stepanova@snau.edu.ua
}

\begin{abstract}
In order to solve the problems associated with expanding range of sausage meat component of high biological value, a search was conducted for alternative, natural and affordable sources of protein. Protein deficiency in human nutrition has led to the search for ways to increase biological value. It was proposed the optimal ratio of components of sausage meat, consisting of meat and mushroom raw materials. The purpose of this combination is to achieve the composition of sausages to the desired approximation of the "ideal protein" with the established technological effects for this production. The main objective of this work is to study the food and taste qualities of the finished product to expand the range of functional sausages at meat processing enterprises in Ukraine and China. Analysis of these data shows that an increase in the level of meat substitution with mushroom raw materials leads to a redistribution of the mass fractions of moisture, protein, fat and ash. The redistribution of these same indicators is affected by the physical state of the introduced mushroom raw material: powder or finely crushed mass. It was recorded a decrease in the mass fraction of fat by approximately $3 \%$ and $6 \%$, respectively. Therefore, it was noted a decrease in energy value from $362 \mathrm{kcal}$ to 335-304 kcal. The proportion of carbohydrates in the experimental samples has increased by an average of 1-2\%. The mass fraction of protein remained almost unchanged, but the composition of the protein was closer to the "ideal protein". According to the results of organoleptic evaluation, it was found that when developing recipes for cooked smoked sausages, it is advisable to add boiled mushrooms in an amount of $15-20 \%$ in finely crushed form. It is advisable to add in the amount of $3.0-7.0 \%$ at the mixing stage in the form of a dry powder of fried mushrooms. The data presented in this article make it possible to assess the prospects of the food industry in the production of sausages enriched with semi-finished products of varying degrees of readiness based on cultivated mushrooms. The results of the analytical study reflect the unique degree of the cultivated mushrooms amino acid composition approximation to the "ideal protein". Particular attention was paid to essential (limiting) amino acids and their content in new types of sausages
\end{abstract}

Keywords: cultivated mushrooms; mushroom powder; biological value; sausages; protein deficiency

\section{ПЕРСПЕКТИВИ ВИКОРИСТАННЯ КУЛЬТИВОВАНИХ ГРИБІВ У ТЕХНОЛОГІЇ КОВБАСНИХ ВИРОБІВ}

\section{Т. М. СТЕПАНОВА ${ }^{1 *}$, Н. В. КОНДРАТЮК ${ }^{2}$, Н. ХАЙЦЗЮНЬ ${ }^{1}$, К. Є. СУПРУНЕНКО}

\author{
${ }^{I}$ кафедра технології харчування, Сумський начіональний аграрний університет, Суми, УКРАЇНА \\ ${ }^{2}$ кафедра харчових технологій, Дніпровський начіональний університет імені Олеся Гончара, Дніпро, УКРАЇНА
}

\begin{abstract}
АНОТАЦІЯ Для вирішення проблем, пов'язаних з розширенням асортименту ковбасних виробів підвищеної біологічної цінності, був проведений пошук альтернативних, природних і доступних джерел білка. Такими пропонується розглядати культивовані гриби. Дефіцит білка в рачіон харчування людей, давно вже став причиною пошуку способів підвищення біологічної цінності, тому ми пропонуємо оптимальні співвідношення компонентів ковбасного фаршу, що складасться 3 м'ясного та грибного сировини. Метою такого комбінування є досягнення складу ковбасних виробів до бажаного наближення до "ідеального білку" при встановлених технологічних ефектах для даного виробництва. Основним завданням роботи є вивчення харчових і смакових якостей готової продукиї для розширення асортименту функиіональних ковбасних виробів на м'ясопереробних підприємствах Украӥни і Китаю. Аналіз наведених даних показує, щяо зі збільшенням рівня заміни м'яса грибним сировиною проходить перерозподіл масових часток вологи, білка, жиру і зольності. На перерозподіл иих же показників впливає фізичний стан внесеного грибного сировини: порошок або тонко подрібнена маса. Було зафіксовано зменшення масової частки жиру приблизно на 3\% і 6\% відповідно. Отже, зниження енергетичної цінності: 3 362 ккал до 335 - 304 ккал. Частка вуглеводів у дослідних зразках збільшувалася в середньому на 1-2\%. Масова частка білка залишалася практично незмінною, але склад білка був ближчий до "ідеального білку". За результатами органолептичної оцінки з'ясовано, щзо при розробці рецептур варено-копчених ковбас доцільно вносити варені гриби в кількості 15 - $20 \%$ в тонкоподрібненому вигляді. У вигляді сухого порошку з обсмажених грибів - в кількості 3,0 - 7,0\% на етапі перемішування. Наведені в статті дані, дозволяють оцінити перспективу напрямків харчової промисловості в сфері виробництва ковбасних виробів, збагачених напівфабрикатами різного ступеня готовності на основі культивованих грибів. Результати аналітичного дослідження, відображають унікальну ступінь наближення амінокислотного складу культивованих грибів до "ідеального білку". Особливу увагу приділено есенціальним (лімітуючим) амінокислотам, їх вмісту в складі нових видів ковбасних виробів.
\end{abstract}

Ключові слова: культивовані гриби; грибний порошок; біологічна ијінність; ковбасні вироби; дефіцит білка

\section{Introduction}

Food products are an integral and non-alternative part of the human life support fund. Long-term deficiency in the diet of certain groups of food products, upsets the balance of food components, and synthesis of substances. The search and involvement in the technological process 
of raw materials that have a balanced chemical composition and have a functional effect is the key to creating high-quality food products that have a beneficial effect on the human body. One way to develop technology is to combine various types of raw materials to achieve a certain type of balance: nutrient, micro- and macroelement, vitamin, fatty acid and the like. However, protein deficiency remains a major problem for humanity. Cultivated mushrooms have a balanced composition of nutrients, they also grow quickly, without requiring expensive equipment for growing, are easily processed, have a pleasant taste and aroma when ready [1]. Fungi have antioxidant, antitumor and anti-inflammatory properties [2]. Sausages are a fairly demanded product in both Ukraine and China. However, premade sausages differ in organoleptic characteristics, based on the taste preferences of different nations. However, the technological process for the production of sausages does not have fundamental disagreements. Thereby, the use of fungi raw materials in sausage technology as an alternative source of protein and nutrients is very relevant especially for Ukraine and China.

\section{The aim of the study}

Analysis of the chemical, in particular amino acid composition of cultivated edible mushrooms with the aim of using them in the technology of cooked smoked sausages enriched with functional ingredients.

\section{Statement of the main material}

Cultivated edible mushrooms are widely popular among the population due to their high palatability, low calorie content and low cholesterol content. According to FOA / WHO statistics, China holds a leading position in the market of cultivated fungi producers (up to 5 thousand tons / year) [3].

Edible cultivated mushrooms are widely represented on the modern market, such as (Agaricus bisporus bicuspid champignons, Brazilian champignon Agaricus subrufescens, common oyster mushroom Pleurotus ostreatus, flamulin or enokitake Flammulina velutipes, edible lentil or shiitodedes etc.). The nutritional value of mushrooms depends on the species, stage of development and environmental conditions [4].

The raw protein content in mushrooms ranges from 12 to $35 \%$, depending on the species. The composition of free amino acids is very different, but in general they are rich in threonine and valine, but are poor in sulfur-containing amino acids.

The carbohydrate profile of mushrooms is represented by starch, pentoses, hexoses, disaccharides, aminocucriva. The total carbohydrate content in mushrooms ranges from $26-82 \%$ based on dry matter in different mushrooms. The raw fibrous composition of the fungus consists of the frequently assimilated polysaccharides and chitin.
Edible fungi are usually low in lipids with a higher proportion of polyunsaturated fatty acids. All this indicates a low calorie content of mushrooms. In addition, mushrooms do not contain cholesterol. But they have ergosterol, which acts as a precursor to the synthesis of vitamin $\mathrm{D}$ in the human body.

The nutritional value of various types of cultivated edible mushrooms, which are planned to be used in the technology of cooked smoked sausages tastes of the Ukrainian and Chinese populations, are represented in table $1[4]$.

Table 1 - Nutritional value of cultivated edible mushrooms (in dry matter gram per $100 \mathrm{~g}$ )

\begin{tabular}{|c|c|c|c|c|}
\hline $\begin{array}{c}\text { Kinds of } \\
\text { mushrooms }\end{array}$ & Proteins & Fats & $\begin{array}{c}\text { Carbohyd } \\
\text { rates }\end{array}$ & Ash \\
\hline $\begin{array}{c}\text { Agaricus } \\
\text { bisporous }\end{array}$ & 33.48 & 3.10 & 46.17 & 5.70 \\
\hline $\begin{array}{c}\text { Pleurotus } \\
\text { ostreatus }\end{array}$ & 30.40 & 2.20 & 57.60 & 9.80 \\
\hline $\begin{array}{c}\text { Flammulina } \\
\text { velutipes }\end{array}$ & 17.60 & 1.90 & 73.10 & 7.40 \\
\hline $\begin{array}{c}\text { Lentinula } \\
\text { edodes }\end{array}$ & 32.93 & 3.73 & 47.60 & 5.20 \\
\hline $\begin{array}{c}\text { Vovarella } \\
\text { volvaceae }\end{array}$ & 37.50 & 2.60 & 54.80 & 1.10 \\
\hline
\end{tabular}

As can be seen from the table 1, high nutritional value determines the widespread use of mushrooms in the technology of low-calorie production, due to the low content of fats in them, as well as an alternative source of protein.

Due to the unique chemical composition, fungi are a promising functional raw material with antioxidant, antimicrobial, hepatosis and anti-cancer effects [5].

Mushrooms occupy a leading position in terms of protein content compared to vegetables [6]. The high biological value of fungal proteins is due to the content of essential amino acids in them. The content of essential amino acids in proteins of fungi compared to the "ideal protein" are shown in table 2 [2].

As can be seen from table 2, cultivated mushrooms have a significant content of essential amino acids, close to their amount in the "ideal protein", which allows us to predict the prospects of using this type of raw material as a source of high-grade protein and minnow meat.

The carbohydrate component of fungi is predominantly represented by $\beta$-glucans by polymers, as well as chitin, mannan, galactans and xylan [7] The digestive enzymes secreted by the pancreas cannot hydrolyze the $\beta$-glucosidic bond, fungal polysaccharides, therefore, indigestible carbohydrates can act as prebiotics in the human body [8]. The authors [9] noted the influence of non-digestible polysaccharides of fungi on the growth of 
Table 2 - The content of essential amino acids in proteins of mushrooms, compared with the "ideal protein"

\begin{tabular}{|c|c|c|c|c|c|c|c|c|c|}
\hline \multirow{2}{*}{$\begin{array}{l}\text { Amino acids } \\
\text { name }\end{array}$} & \multicolumn{9}{|c|}{ The content of this amino acid, g per $100 \mathrm{~g}$ of protein } \\
\hline & $\begin{array}{l}\text { Perfect } \\
\text { protein }\end{array}$ & $\begin{array}{c}\text { Oyster } \\
\text { mushroom }\end{array}$ & Shiitake & Enoki & $\begin{array}{c}\text { Flammulina } \\
\text { velutipes }\end{array}$ & $\begin{array}{l}\text { Vovarella } \\
\text { volvaceae }\end{array}$ & $\begin{array}{c}\text { Agaricus } \\
\text { bisporus }\end{array}$ & $\begin{array}{l}\text { Pleurotus } \\
\text { eryngii }\end{array}$ & $\begin{array}{c}\text { Straw } \\
\text { mushroom }\end{array}$ \\
\hline $\begin{array}{c}\text { Essential } \\
\text { amino acids }\end{array}$ & 36.0 & 42.7 & 45.7 & 77.9 & 31.6 & 39.4 & 69.3 & 38.8 & 43.8 \\
\hline Valine & 5.0 & 5.0 & 5.2 & 7.1 & 3.0 & 2.7 & 8.1 & 4.3 & 6.3 \\
\hline Isoleucine & 4.0 & 3.8 & 4.7 & 11.9 & 3.6 & 4.0 & 16.4 & 2.3 & 5.3 \\
\hline Luecine & 7.0 & 8.8 & 9.2 & 11.4 & 5.6 & 8.2 & 14.3 & 2.3 & 7.3 \\
\hline Lysine & 5.5 & 5.0 & 5.6 & 15.4 & 3.9 & 5.2 & 13.0 & 0.6 & 6.2 \\
\hline $\begin{array}{l}\text { Methionine } \\
\text { +Cystine }\end{array}$ & 3.5 & 7.5 & 6.0 & 7.1 & 3.8 & 5.4 & 4.3 & 15.6 & 6.7 \\
\hline Threonine & 4.0 & 4.2 & 4.8 & 7.8 & 3.4 & 5.0 & 4.3 & 3.0 & 5.2 \\
\hline $\begin{array}{l}\text { Phenylalanine } \\
\text { +Tyrosine }\end{array}$ & 6 & 6.9 & 9.0 & 13.7 & 7.1 & 7.0 & 5.6 & 9.7 & 6.7 \\
\hline Tryptophan & 1 & 1.5 & 1.2 & 3.4 & 1.2 & 1.9 & 3.2 & 1.0 & 0.1 \\
\hline $\begin{array}{l}\text { Nonessential } \\
\text { amino acids }\end{array}$ & - & 54.0 & 55.2 & 100.4 & 34.7 & 50.9 & 78.0 & 34.5 & 52.7 \\
\hline Arginine & - & 5.4 & 5.3 & 12.8 & 4.3 & 5.5 & 8.8 & 2.4 & 4.9 \\
\hline Glutamic acid & - & 16.6 & 11.5 & 27.8 & 7.3 & 11.9 & 12.7 & 6.3 & 14.0 \\
\hline Alanine & - & 8.2 & 9.9 & 10.3 & 5.4 & 8.2 & 9.2 & 4.2 & 9.7 \\
\hline Glycine & - & 6.1 & 10.3 & 8.0 & 4.1 & 5.4 & 6.7 & 2.6 & 6.9 \\
\hline $\begin{array}{l}\text { Asparaginic } \\
\text { acid }\end{array}$ & - & 9.8 & 7.8 & 16.9 & 7.3 & 10.5 & 22.9 & 7.3 & 8.6 \\
\hline Proline & - & 1.7 & 3.4 & 12.2 & 1.9 & 3.0 & 8.2 & 7.7 & 2.1 \\
\hline Serine & - & 4.2 & 4.7 & 7.0 & 2.7 & 3.4 & 7.4 & 2.9 & 4.2 \\
\hline Histidine & - & 1.9 & 2.2 & 5.5 & 1.5 & 2.9 & 2.0 & 1.3 & 2.3 \\
\hline $\begin{array}{l}\text { Total amino } \\
\text { acid }\end{array}$ & - & 96.7 & 100.9 & 178.4 & 66.2 & 90.3 & 147.3 & 73.3 & 96.5 \\
\hline
\end{tabular}

beneficial bacteria in the human gastrointestinal tract. A stable antimicrobial effect against a number of pathogens (Bacillus cereus, Staphylococcus aureus and Salmonella typhimurium) was also noted [10].

The carbohydrate component of fungi is predominantly represented by $\beta$-glucans by polymers, as well as chitin, mannan, galactans and xylan [7] The digestive enzymes secreted by the pancreas cannot hydrolyze the $\beta$-glucosidic bond, fungal polysaccharides, therefore, indigestible carbohydrates can act as prebiotics in the human body [8]. The authors [9] noted the influence of non-digestible polysaccharides of fungi on the growth of beneficial bacteria in the human gastrointestinal tract. A stable antimicrobial effect against a number of pathogens (Bacillus cereus, Staphylococcus aureus and Salmonella typhimurium) was also noted [10].
Edible cultivated mushrooms are a good source of vitamins, in particular B vitamins (thiamine B1, riboflavin B2, niacin B3, pantothenic acid B5 and folate B9), vitamins $\mathrm{D}$ and $\mathrm{E}$ [11], as well as minerals (K, Ca, P, Na, $\mathrm{Mg})$ [12].

Thus, mushrooms are quite attractive as food ingredients for enrichment, for their nutritional value, safety and affordability.

\section{The discussion of the results}

Given high nutritional and biological value, edible cultivated mushrooms are widely used in the food industry. However, the technology of such popular products as cooked smoked sausages requires the attention and intervention of scientific technologists.

The authors of [13] found that they were in good condition for the hour of free champagne at the 
fermentation of fermented pork sausages. There was also a reduction in the number of products for the market share of frequent replacement of meat from the Syrovini.

While using mushroom raw materials in amount of $15-30 \%$ in the technology of beef sausages, the authors [14] of established improvements in the technological properties of the finished product, and an increase in the content of essential amino acids to $10 \%$, as well as a decrease in fat content compared to analogues.

The authors note [15] the improvement in the quality indicators of the finished product when using edible cultivated mushrooms in the form of a powder in the production of chicken sausages.

Table 3 shows the chemical composition of the developed samples.

Table 3 - The chemical composition of the samples developed cooked smoked sausages and their analogue

\begin{tabular}{|c|c|c|c|c|c|c|}
\hline \multirow{2}{*}{ Sample Name } & \multicolumn{5}{|c|}{ Content, \% } & \multirow{2}{*}{$\begin{array}{c}\text { Energy value, } \\
\text { kcal }\end{array}$} \\
\cline { 2 - 6 } & Humidity & Protein & Fat & Carbohydrate & Ash & 468 \\
\hline $\begin{array}{c}\text { Sausage cooked smoked "Cervelat" } \\
\text { (control) }\end{array}$ & $29,1 \pm 0,1$ & $24,0 \pm 0,1$ & $40,5 \pm 0,1$ & $0,20 \pm 0,01$ & $6,2 \pm 0,1$ & 455 \\
\hline $\begin{array}{c}\text { Sausage cooked smoked with fried } \\
\text { mushroom powder (sample 1) }\end{array}$ & $31,2 \pm 0,1$ & $23,3 \pm 0,1$ & $39,4 \pm 0,1$ & $0,14 \pm 0,01$ & $6,1 \pm 0,1$ & 451 \\
\hline $\begin{array}{c}\text { Sausage cooked smoked with finely } \\
\text { ground mass of cooked mushrooms } \\
\text { (sample 2) }\end{array}$ & $41,6 \pm 0,1$ & $19,6 \pm 0,1$ & $32,6 \pm 0,1$ & $0,94 \pm 0,01$ & $5,2 \pm 0,1$ & 381 \\
\hline
\end{tabular}

For the quality of meat and sausage minced meat, as well as finished products corresponds to such a rheological indicator as water-binding ability.

During cooking, the free moisture contained in the mushrooms is removed, and bound contains protein and hydrocarbon structures. As a result of fine grinding of the tissues of meat and mushrooms, the particle size decreases, and their total surface increases. Moisture turns into surface-bound moisture; the losses of sausages during heat treatment were insignificant. The use of mushroom raw materials in the production of cooked smoked sausages affected the content of the mass fraction of moisture. The value of the humidity indicator presented in the Table 3. The results of the organoleptic assessment (on a 5-point scale) of the quality of cooked smoked control sausages and experimental samples using a mushroom ingredient are presented in table 4.

Table 4 - Organoleptic characteristics of boiled sausages of research and control samples

\begin{tabular}{|c|c|c|c|}
\hline $\begin{array}{c}\text { Parameter } \\
\text { name }\end{array}$ & $\begin{array}{c}\text { Sausage cooked smoked "Cervelat" } \\
\text { (control) }\end{array}$ & $\begin{array}{c}\text { Sausage cooked smoked } \\
\text { with fried mushroom } \\
\text { powder (sample 1) }\end{array}$ & $\begin{array}{c}\text { Sausage cooked smoked with } \\
\text { finely ground mass of cooked } \\
\text { mushrooms (sample 2) }\end{array}$ \\
\hline Appear & Attractive cutaway appearance, evenly mixed meat with single pores \\
\hline $\begin{array}{c}\text { Cutaway } \\
\text { color }\end{array}$ & Pink & Pale pink & Gray pink \\
\hline $\begin{array}{c}\text { Smell and } \\
\text { Taste }\end{array}$ & $\begin{array}{c}\text { Pleasant, characteristic of this } \\
\text { product, without strangers, with the } \\
\text { aroma of spices, moderately salty }\end{array}$ & $\begin{array}{c}\text { Well defined, pleasant, } \\
\text { without extraneous smacks } \\
\text { and odors }\end{array}$ & $\begin{array}{c}\text { Well defined, pleasant, without } \\
\text { extraneous smacks and odors }\end{array}$ \\
\hline Consistency & Dense & Tender, firm, tight & Tender, firm, tight \\
\hline
\end{tabular}

\section{Conclusions}

Thereby, the high nutritional and biological value of mushrooms, the indicated functional properties of edible cultivated mushrooms allow their use in the production of cooked smoked sausages in order to improve consumer properties, reduce calorie content, as well as produce functional products. In addition, for the Ukrainia n population, replacing part of the sausage meat with a finely ground mass of boiled mushrooms or with dry powder from fried mushrooms will reduce the use of soya-based minced meat substitutes. For the Chinese population, the problem of processing mushrooms, whose production is more than 5 thousand tons per year, will be solved.

\section{Список литературы}

1. Mattila, P. Functional Properties of Edible Mushrooms / P. Mattila // Nutrition. - 2000. - № 16. - P. 694-696. - doi: 10.1016/s0899-9007(00)00341-5.

2. Wani, B. A. Nutritional and medicinal importance of mushrooms / B. A. Wani // Journal of medicinal plant research. - 2010. - № 4(24). - P. 2598-2604. doi:10/5897/JMPR09.565.

3. Food and Agriculture Organization of the United Nations, Statistics Division (FAOSTAT) Crops Production. URL: http://faostat.fao.org.

4. Suresh, C. Nutritional and medicinal aspects of edible mushrooms / C. Suresh // International Journal of Agriculture Sciences. - 2006. - № 2. - P. 647-651.

5. Khatun, S. Mushroom as a Potential Source of Nutraceuticals / S. Khatun // American Journal of 
Experimental Agriculture. - 2012. - № 2(1). - P. 47-73. doi: 10.9734/AJEA/2012/492.

6. Wang, X. M. A mini-review of chemical composition and nutritional value of edible wild-grown mushroom from China / X. M. Wang // Food Chemistry. - 2014. - № 151. P. 279-285. - doi: 10.1016/j.foodchem.2013.11.062.

7. Friedman, M. Mushroom Polysaccharides: Chemistry and Antiobesity, Antidiabetes, Anticancer, and Antibiotic Properties in Cells, Rodents, and Humans / M. Friedman // Foods. - 2016. - № 5(4). - P. 2-40. doi: $10.3390 /$ foods 5040080 .

8. Sawangwan, T. Study of prebiotic properties from edible mushroom extraction / T. Sawangwan // Agriculture and Natural Resources. - 2018. - № 52(6). - P. 519-524. - doi 10.1016/j.anres.2018.11.020.

9. Gao, S. Nondigestible carbohydrates isolated from medicinal mushroom sclerotia as novel prebiotics / S. Gao // International Journal of Medicinal Mushrooms. - 2009. - № 11. - P. 1-8. - doi: 10.1615/IntJMedMushr.v11.i1.10.

10. Tinrat, S. Antimicrobial activities and synergistic effects of the combination of some edible mushroom extracts with antibiotics against pathogenic strains / S. Tinrat // International Journal of Pharmaceutical Sciences Review and Research. - 2015. - № 35. - P. 253-262.

11. Kutaiba, I. A. Chemical composition and nutritional value of edible mushrooms: a review / I. A. Kutaiba // World Journal of Pharmaceutical Research. - 2018. - № 8 (1). P. 31-46. - doi: 10.20959/wjpr20193-14261.

12. Mallikarjuna, S. E. Mineral Composition of Four Edible Mushrooms / S. E. Mallikarjuna // Journal of Chemistry. 2013. - № 8 (1). - P. 31-46. - doi: 10.1155/2013/805284.

13. Chockchaisawasdee, $\mathbf{S}$. Development of fermented oystermushroom sausage / S. Chockchaisawasdee // Asian Journal of Food and Agro Industry. - 2010. - № 3 (01). - P. $35-43$.

14. Dalaeen, S. Utilization of mushroom fungi in processing of meat sausage / S. Dalaeen // Research on Crops. - 2018. № 19 (2). - P. 294-299. - doi: 10.5958/23487542.2018.00044.X.

15. Jo, K. Quality characteristics of low-salt chicken sausage supplemented with a winter mushroom powder / K. Jo // Korean Journal for Food Science of Animal Resources. -

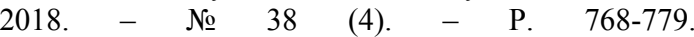
doi: 10.5851/kosfa.2018.e15.

\section{References (transliterated)}

1. Mattila, P. Functional Properties of Edible Mushrooms. Nutrition, 2000, 16, 694-696, doi: 10.1016/s08999007(00)00341-5.
2. Wani, B. A. Nutritional and medicinal importance of mushrooms. Journal of medicinal plant research, 2010, 4(24), 2598-2604, doi:10/5897/JMPR09.565.

3. Food and Agriculture Organization of the United Nations, Statistics Division (FAOSTAT) Crops Production. Available at: http://faostat.fao.org.

4. Suresh, C. Nutritional and medicinal aspects of edible mushrooms. International Journal of Agriculture Sciences, 2006, 2, 647-651.

5. Khatun, S. Mushroom as a Potential Source of Nutraceuticals. American Journal of Experimental $\begin{array}{llll}\text { Agriculture, } & 2012, & \text { 2(1), } & 47-73,\end{array}$ doi: 10.9734/AJEA/2012/492.

6. Wang, X. M. A mini-review of chemical composition and nutritional value of edible wild-grown mushroom from China. Food Chemistry, 2014, 151, 279-285, doi: 10.1016/j.foodchem.2013.11.062.

7. Friedman, M. Mushroom Polysaccharides: Chemistry and Antiobesity, Antidiabetes, Anticancer, and Antibiotic Properties in Cells, Rodents, and Humans. Foods, 2016, 5(4), 2-40, doi: 10.3390/foods5040080.

8. Sawangwan, T. Study of prebiotic properties from edible mushroom extraction. Agriculture and Natural Resources, 2018, 52(6), 519-524, doi: 10.1016/j.anres.2018.11.020.

9. Gao, S. Nondigestible carbohydrates isolated from medicinal mushroom sclerotia as novel prebiotics. International Journal of Medicinal Mushrooms, 2009, 11, 18, doi: 10.1615/IntJMedMushr.v11.i1.10.

10. Tinrat, S. Antimicrobial activities and synergistic effects of the combination of some edible mushroom extracts with antibiotics against pathogenic strains. International Journal of Pharmaceutical Sciences Review and Research, 2015, 35, 253-262.

11. Kutaiba, I. A. Chemical composition and nutritional value of edible mushrooms: a review. World Journal of Pharmaceutical Research, 2018, 8 (1), 31-46, doi: 10.20959/wjpr20193-14261.

12. Mallikarjuna, S. E. Mineral Composition of Four Edible Mushrooms. Journal of Chemistry, 2013, 8 (1), 31-46, doi: $10.1155 / 2013 / 805284$

13. Chockchaisawasdee, S. Development of fermented oystermushroom sausage. Asian Journal of Food and Agro Industry, 2010, 3 (01), 35-43.

14. Dalaeen, $\mathbf{S}$. Utilization of mushroom fungi in processing of meat sausage. Research on Crops, 2018, 19 (2), 294-299, doi: 10.5958/2348-7542.2018.00044.X.

15. Jo, K. Quality characteristics of low-salt chicken sausage supplemented with a winter mushroom powder. Korean Journal for Food Science of Animal Resources, 2018, 38 (4), 768-779, doi: 10.5851/kosfa.2018.e15.

\section{Сведения об авторах (About authors)}

Tetiana Stepanova - Candidate of Technical Sciences (Ph. D.), Docent, Department of Food Technology, Sumy National Agrarian University, Sumy, Ukraine; ORCID: https://orcid.org/0000-0002-9392-3773; e-mail: tetiana.stepanova@snau.edu.ua.

Степанова Тетяна Михайлівна - кандидат технічних наук, доцент, доцент кафедри технології харчування, Сумський національний аграрний університет, м Суми, Україна; ORCID: https://orcid.org/0000-0002-9392-3773; e-mail: tetiana.stepanova@snau.edu.ua.

Natalia Kondratjuk - Candidate of Technical Sciences (Ph. D.), Docent, Head of the Department, Department of Food Technlogies, Oles Honchar Dnipro National University, Dnipro, Ukraine; ORCID: https://orcid.org/0000-0003-4578-9108; e-mail: kondratjukn3105@gmail.com.

Кондратюк Наталія Вячеславівна - кандидат технічних наук, доцент, завідувач кафедри харчових технологій, Дніпровський національний університет імені Олеся Гончара, м Дніпро, Україна; ORCID: https://orcid.org/0000-0003-45789108; e-mail: kondratjukn3105@gmail.com.

Nan Haijuan - Postgraduate student, Department of Food Technology, Sumy National Agrarian University, Sumy, Ukraine; ORCID: https://orcid.org/0000-0002-9392-3773; e-mail: nanhaijuan1@163.com. 
Нан Хайдзюн - аспірант кафедри технології харчування, Сумський національний аграрний університет, м Суми, Україна; ORCID: https://orcid.org/0000-0002-9392-3773; e-mail: nanhaijuan1@163.com.

Katerina Suprunenko - Assistant, Department of Food Technlogies, Oles Honchar Dnipro National University, Dnipro, Ukraine; ORCID: https://orcid.org/0000-0002-8741-5449; e-mail: suprunenko.katerina90@gmail.com.

Супруненко Катерина Свгенівна - асистент кафедри харчових технологій, Дніпровський національний університет імені Олеся Гончара, м Дніпро, Україна; ORCID: https://orcid.org/0000-0002-8741-5449; e-mail: suprunenko.katerina90@gmail.com.

Please cite this article as:

Stepanova, T., Kondratjuk, N., Haijuan, N., Suprunenko, K. Prospects of cultivated mushrooms use in technology of sausages. Bulletin of NTU "KhPI". Series: New solutions in modern technologies. - Kharkiv: NTU "KhPI", 2019, 2, 75-80, doi:10.20998/2413-4295.2019.02.11.

Будь ласка, посилайтеся на июю статтю таким чином

Степанова, Т. М. Перспективи використання культивованих грибів у технології ковбасних виробів / Т. М. Степанова, Н. В. Кондратюк, Н. Хайдзюн, К. Е. Супруненко // Вісник НТУ «ХПI», Серія: Нові рімення в сучасних технологіях. - Харьків: НТУ «ХПІ». - 2019. - № 2. - С. 75-80. - doi:10.20998/2413-4295.2019.02.11.

Будь ласка, посилайтесь на иъю статтю наступним чином:

Степанова, Т. М. Перспективы использования культивированных грибов в технологии колбасных изделий / Т. М. Степанова, Н. В. Кондратюк, Н. Хайдзюн, К. Е. Супруненко // Вестник НТУ «ХПИ», Серия: Новые решения 8 современных технологиях. - Харьков: НТУ «ХПИ». - 2019. - № 2. - С. 75-80. - doi:10.20998/2413-4295.2019.02.11.

АННОТАЦИЯ Для решения проблем, связанных с расширением ассортимента колбасных изделий повышенной биологической иенности, был проведен поиск альтернативных, природных и доступных источников белка. Таковыми предлагается рассматривать культивированные грибы. Дефищит белка в рачонах питания людей, давно уже стал причиной поиска способов повышения биологической ценности, поэтому мы предлагаем оптимальные соотношения компонентов колбасного фарша, состоящего из мясного и грибного сырья. Целью такого комбинирования является достижение состава колбасных изделий до желаемого приближения к идеальному белку" при установленных технологических эффектах для данного производства. Основной задачей работы является изучение пищевых и вкусовых качеств готовой продукиии для расширения ассортимента функииональных колбасных изделий на мясоперерабатывающих предприятиях Украины и Китая. Анализ приведенных данных показывает, что с увеличением уровня замены мяса грибным сырьем проходит перераспределение массовых долей влаги, белка, жира и зольности. На перераспределение этих же показателей влияет физическое состояние вносимого грибного сырья: порошок или тонко измельченная масса. Было зафиксировано уменьшение массовой доли жира приблизительно на $3 \%$ и $6 \%$ соответственно. Следовательно, снижение энергетической ценности: с 362 ккал до 335-304 ккал. Доля углеводов в опытных образиах увеличивалась в среднем на 1-2 \%. Массовая доля белка оставалась практически неизменной, но состав белка был более близок к йдеальному белку." По результатам органолептической оиенки выяснено, что при разработке рецептур варено-копченых колбас иелесообразно вносить вареные грибы в количестве 15-20\% в тонкоизмельченном виде. В виде сухого порошка из обжаренных грибов - 8 количестве 3,0-7,0 \% на этапе перемешивания. Приведенные в статье данные, позволяют оценить перспективу направлений пищевой промышленности в сфере производства колбасных изделий, обогащенных полуфабрикатами различной степени готовности на основе культивированных грибов. Результаты аналитического исследования, отражсают уникальную степень приближения аминокислотного состава культивированных грибов к идеальному белку." Особое внимание уделено эссенциальным (лимитирующим) аминокислотам, их содержанию в составе новых видов колбасных изделий.

Ключевые слова: культивированные грибы; грибной порошок; биологическая иенность; колбасные изделия; дефицит белка

Поступила (received) 02.10.2019 